\title{
The Use Of Excel Macro Feature On Cost Estimation Calculation
}

\author{
Putri Lynna A. Luthan ${ }^{1}$, Nathanael Sitanggang ${ }^{2}$ \\ \{putri.lynna@gmail.com ${ }^{1}$, nathanaelsitanggang@unimed.ac.id ${ }^{2}$ \} \\ Faculty of Engineering, Universitas Negeri Medan, Indonesia ${ }^{1,2}$ \\ nathanaelsitanggang@unimed.ac.id
}

\begin{abstract}
This study aims to describe the stages of calculating the construction costs estimation using the Macro feature on Excel. The problem that being studied is how are the stages of using the Excel Macro to determine the volume of steel and the reinforcement model that needed for a construction. The research method used is a qualitative descriptive type with the research subject being a construction project contractor who uses an Excel Macro for a Micro Hydro Power Plant development project. Data is obtained through observation, interviews and reviewing various sources of documents. The results found are the stages of using Excel macros to calculate the number, model of reinforcement, dimensions, code and the amount of residual material produced by the estimator as a guide for workers. This finding is very useful because with the use of Excel macro can improve the estimation work for planning consultants and contractors to be more effective and efficient.
\end{abstract}

Key words: excel macros, cost estimateion, models, steel weights, estimators

\section{Introduction}

Along with the advancement of digital technology that continues to grow rapidly until the current Industrial Revolution 4.0 era, the development of software for Civil Engineering work has also been widely available and used by the plan consultants and construction building contractors to perform calculations quickly and accurately. One of the available software is an Excel macro feature that is used to calculate cost estimation of a construction building. With the availability of this feature, the plan consultant and the contractor can store documents as a database. But based on observations there are still many contractors who have not used the Excel macro feature. The results of these observations are in line with Soeparto and Trigunarsyah [1] and Pramudyo [2] which explain that Information Communication Technology (ICT) in the implementation of construction projects has not been used effectively, so that the Indonesian construction workforce will be less competitive than foreign workers, so it is needed to master the development of Information Technology for construction workers. The challenge faced by planner and contractor today is to prepare the Indonesian construction workers who are professional and able to utilize ICT effectively. A special excel macro feature is used to calculate the use of steel and reinforcement models that will be used in a construction building. Macros are codes or scripts, while Visual Basic is a programming language used to create macros [3]. 
This Excel macro feature does not require a high programming language, with the ability of using Excel we will be able to operate the program that has been designed [4]. The software used in the construction project is designed by the contractor as a construction agent and can only be used by the designer. In order for the software to be used continuously, other resources that can use the feature are needed [5]. The use of the excel macro feature should be trained to estimators who have been able to read the picture and understand how to calculate the calculation.

During this calculation the construction in construction projects still do a lot of manual calculations, so that it has difficulty in managing the Bar Bending Schedule (BBS) on the calculation of the reinforcement. The expected competence in BBS work is to provide data on the number of bars of reinforcement, dimension, weight, shape and code with the help of Excel macro feature. The problem in this research is how are the stages of using Excel macros in calculating the cost estimation of construction buildings? This study describes the work stages that are carried out by estimators to calculate cost using the Excel macro feature. This research is very useful for plan consultants and construction building contractors because it can help the estimator work more effectively and efficiently.

\section{Research Method}

This study uses qualitative research methods with descriptive type. This study seeks to understand the meaning and images derived from individuals and groups [6][7]. Data collection was carried out using observation and interview methods [8] with 1 estimation contractor on Micro Hydro Power Plant construction in Medan City that had used macro excel features on 3 (three) construction projects. Sampling was determined based on purposive sampling technique [9] for estimators using the Excel Macro feature. Data analysis used is thematic analysis techniques that continued with interpretation. The credibility of this research is based on communicative validity, argumentative validity, and ecological validity [8].

The use of excel macro as a calculation tool has been carried out by several researchers such as [10][11]. Usability test with VBA program macro excel feature has an effective value of $58 \%,[10]$ and the level of accuracy of differences in the use of excel macros with manuals is $0.005 \%$ [11].

Research conducted by [12], the prototype built can present the data needed and has been tested by comparing the results of the analysis so that there is a match between the admin and the observer.

According to [13], from the results of testing using the energy audit data of the Electrical Engineering building at Diponegoro University Semarang resulted in the conclusion that the opportunity to save energy is feasible with the Microsoft Excel macro feature.

Based on several literature studies, it can be stated that Excel macros can be used to collect data so that the waste that can occur is as small as possible.

\section{Result And Discussion}

Based on the results of the study, the calculation process of bar bending schedule by using excel macros is done by stages, namely 


\subsection{Preparation phase}

At the preparation stage there are several things that are needed, namely:

1. Ability to operate excel

2. The macro excel feature that has been designed

3. Reinforcement drawings

\subsection{Implementation phase}

After getting the BBS file from the contractor the file is opened, if when the BBS file is opened it turns out that the macro facility in Excel is not active then it must first be activated. To activate macros in excel software, there are several steps, starting from the options-trust settings-macro settings (enable all macros + trust access to the VBA) that can be seen in Fig.1.

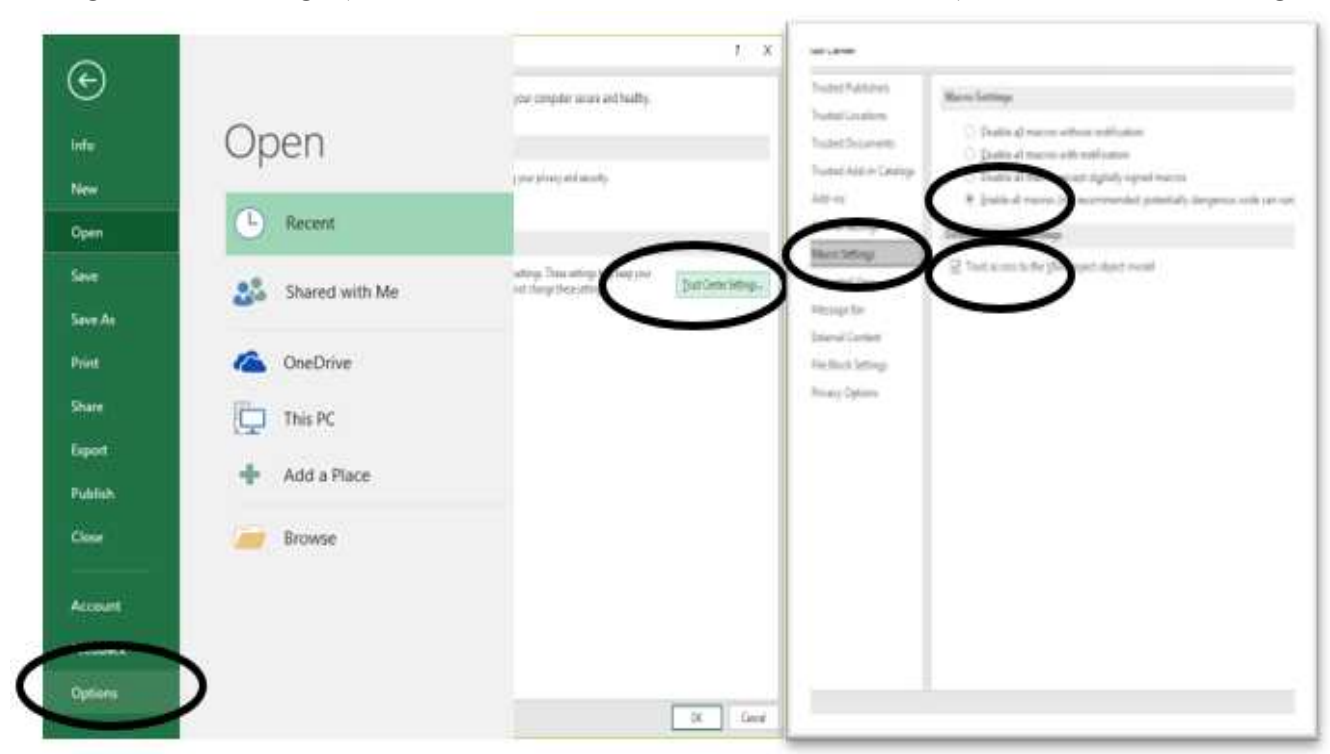

Figure 1 Activate the Excel macro feature

After the steps in Figure 1 are done, then the excel worksheet will lose the security warning command, which can be seen in Figure 2. 


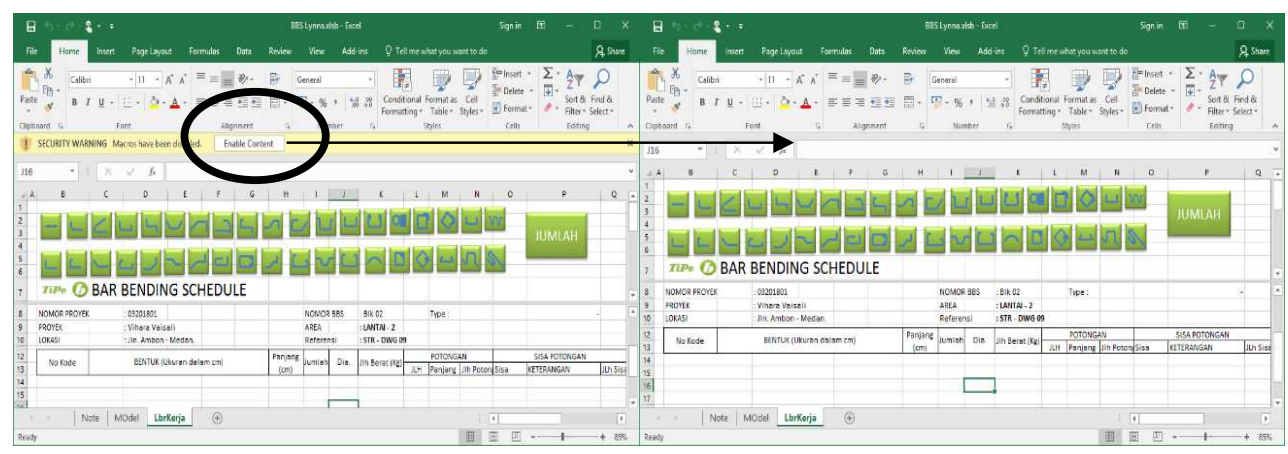

Figure 2 Worksheet without security warning

In Figure 2 we see a work sheet without a security warning, this worksheet is what we will use to operate the calculation of forms and models of reinforcement. On the worksheet there are various forms of reinforcement used for the cleaning work shown in Figure 3. The next step is to place the cursor under the code written in Figure 4, then to choose the reinforcement model in Figure 3 that will be calculated according to the working picture.

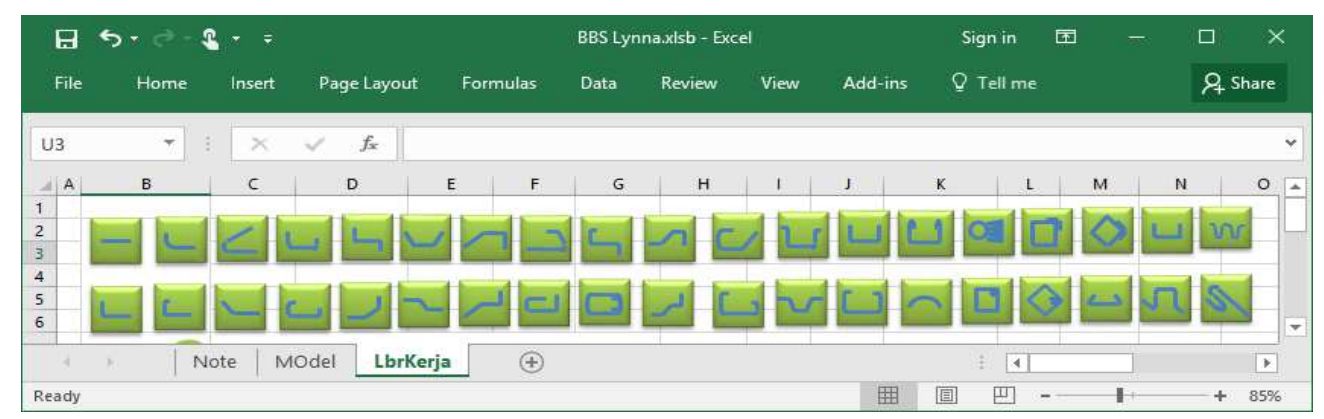

Figure 3 Reinforcement model

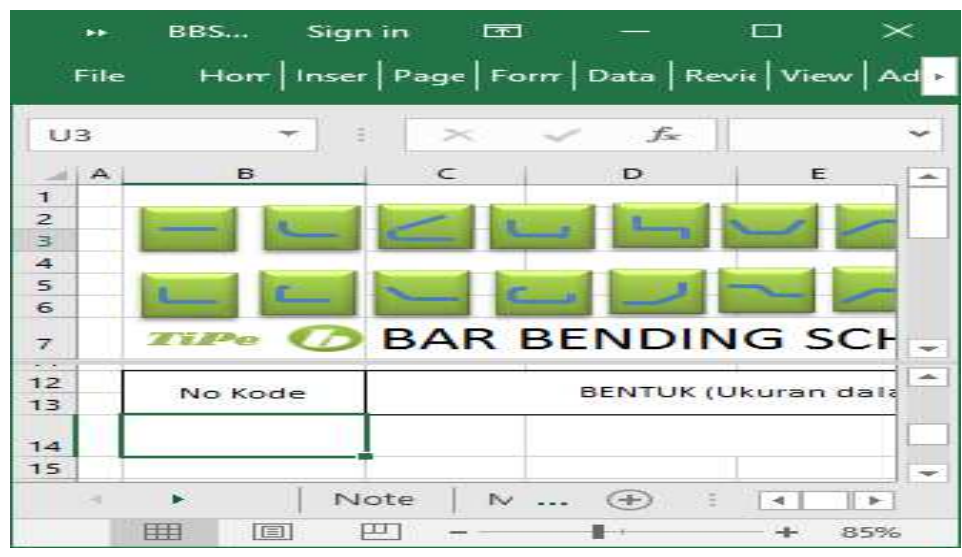

Figure 4 Initial steps 
In Figure 4, the first step to start calculating with an Excel macro is to place the cursor in the 14th row of $b$ column, then choose the reinforcement model to be used, the worksheet will look like in Figure 5.

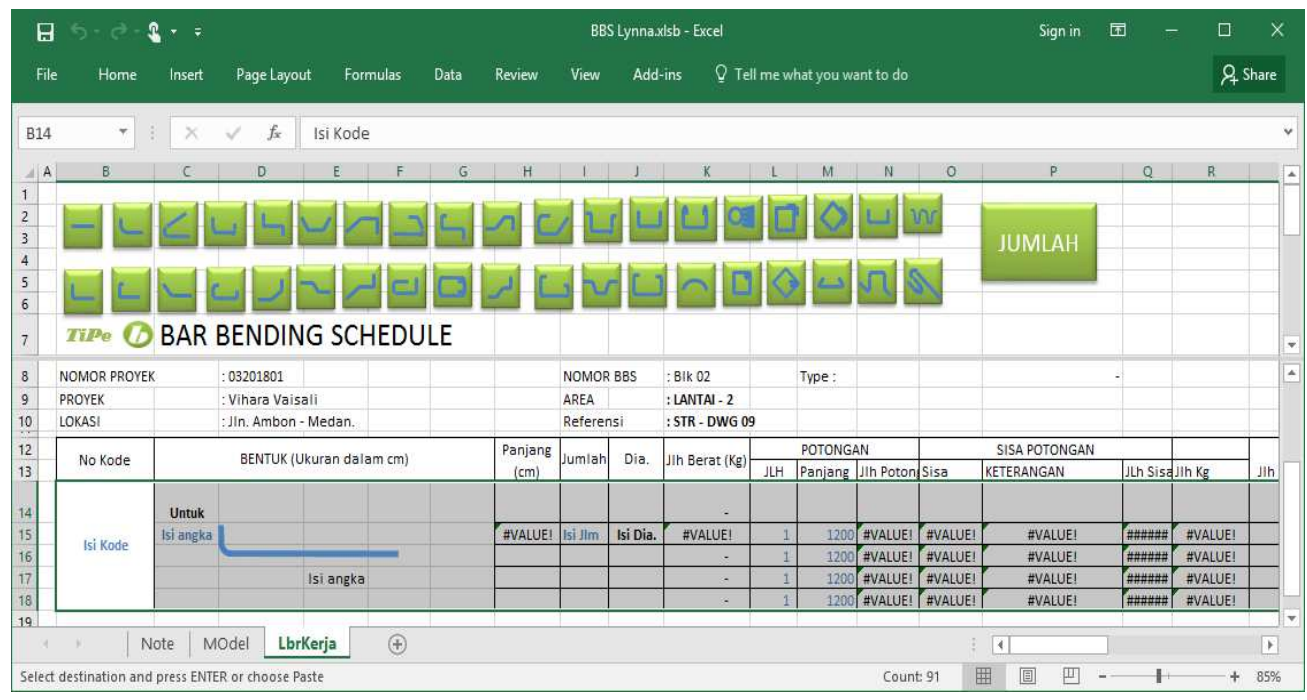

Figure 5 Input data according to work drawings

With the emergence of a reinforcement model on the worksheet, do fill in the code, size, number of diameters. The computer automatically calculates to get the required amount of weight shown in column $\mathrm{K}$ shown in Figure 6.

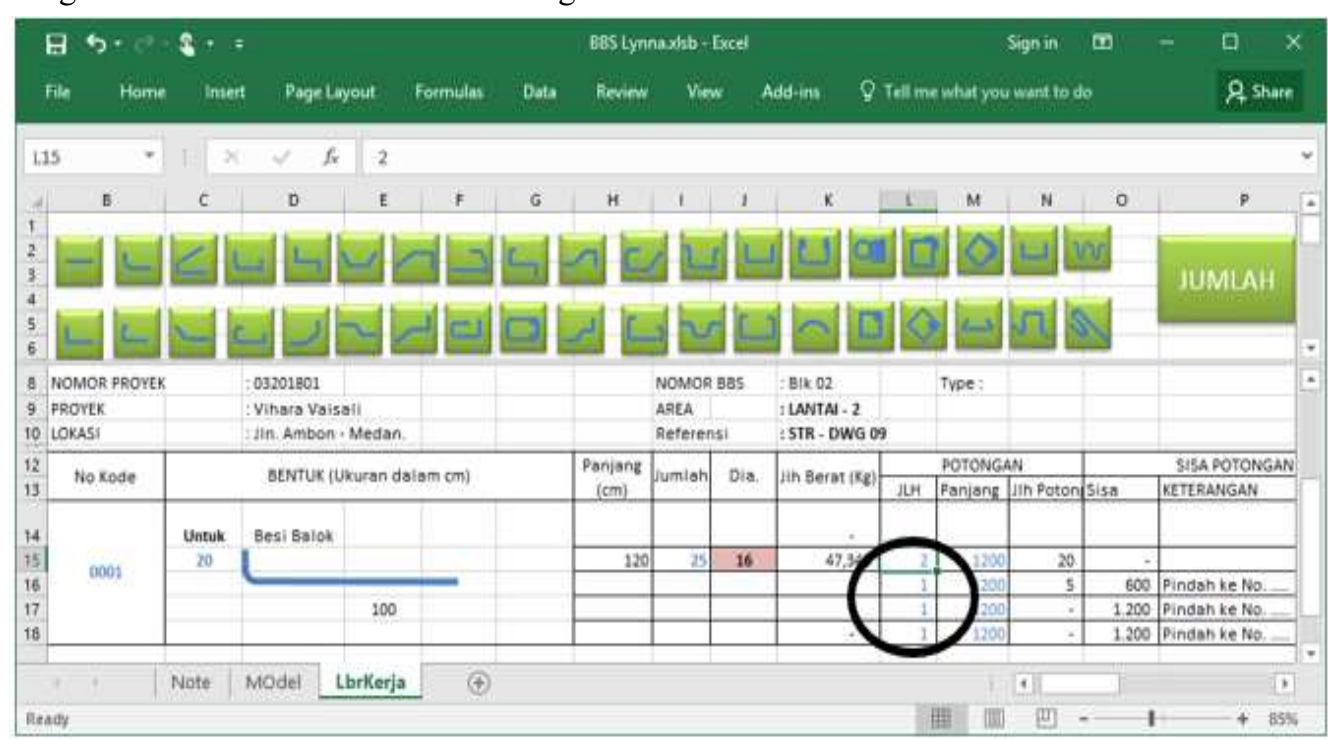

Figure 6 Weight of steel 
The next step is the data entry of the number of pieces and length of steel based on the work picture which can be seen in Figure 7.

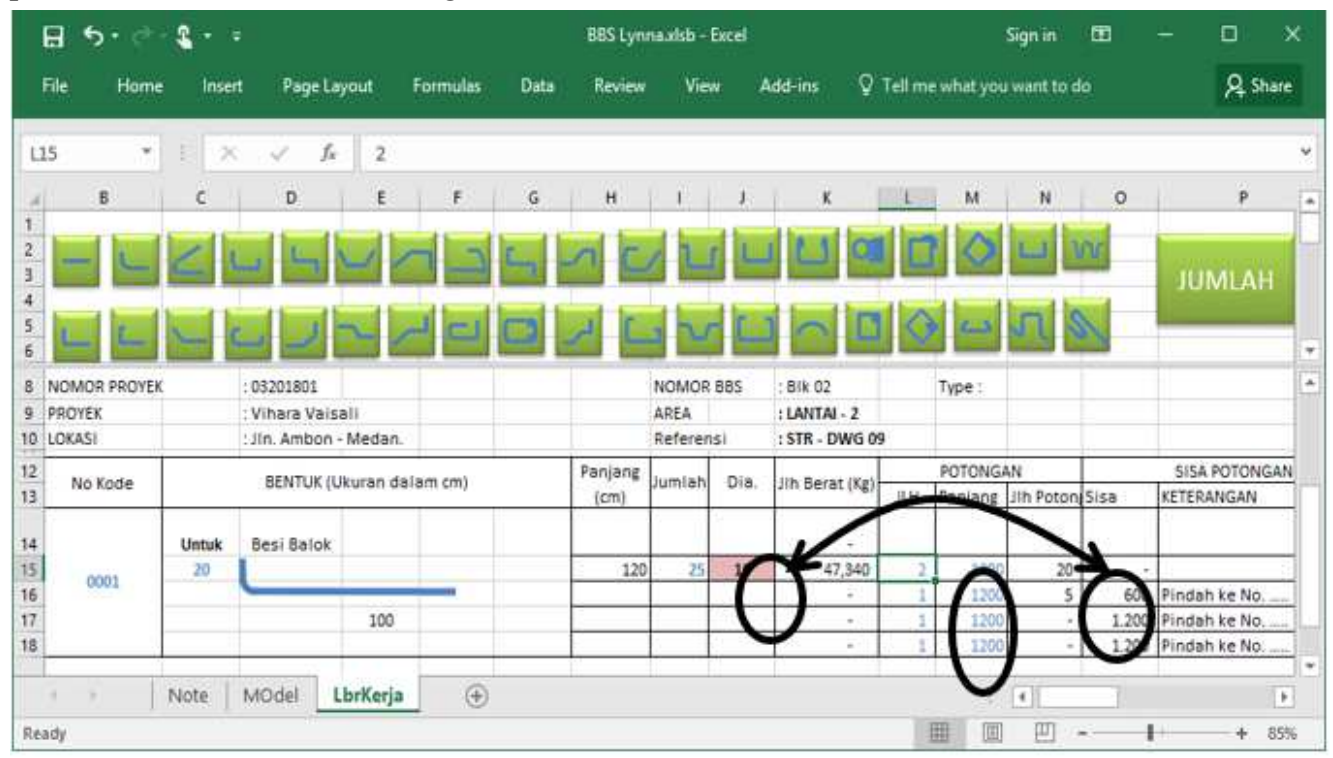

Figure 7 Data input on the number and length of steel

In reinforcement type construction projects used various models and sizes, models and sizes used based on images for construction of consultant planners. The next stage is the input process of reinforcement models and other shapes which can be seen in Figure 8.

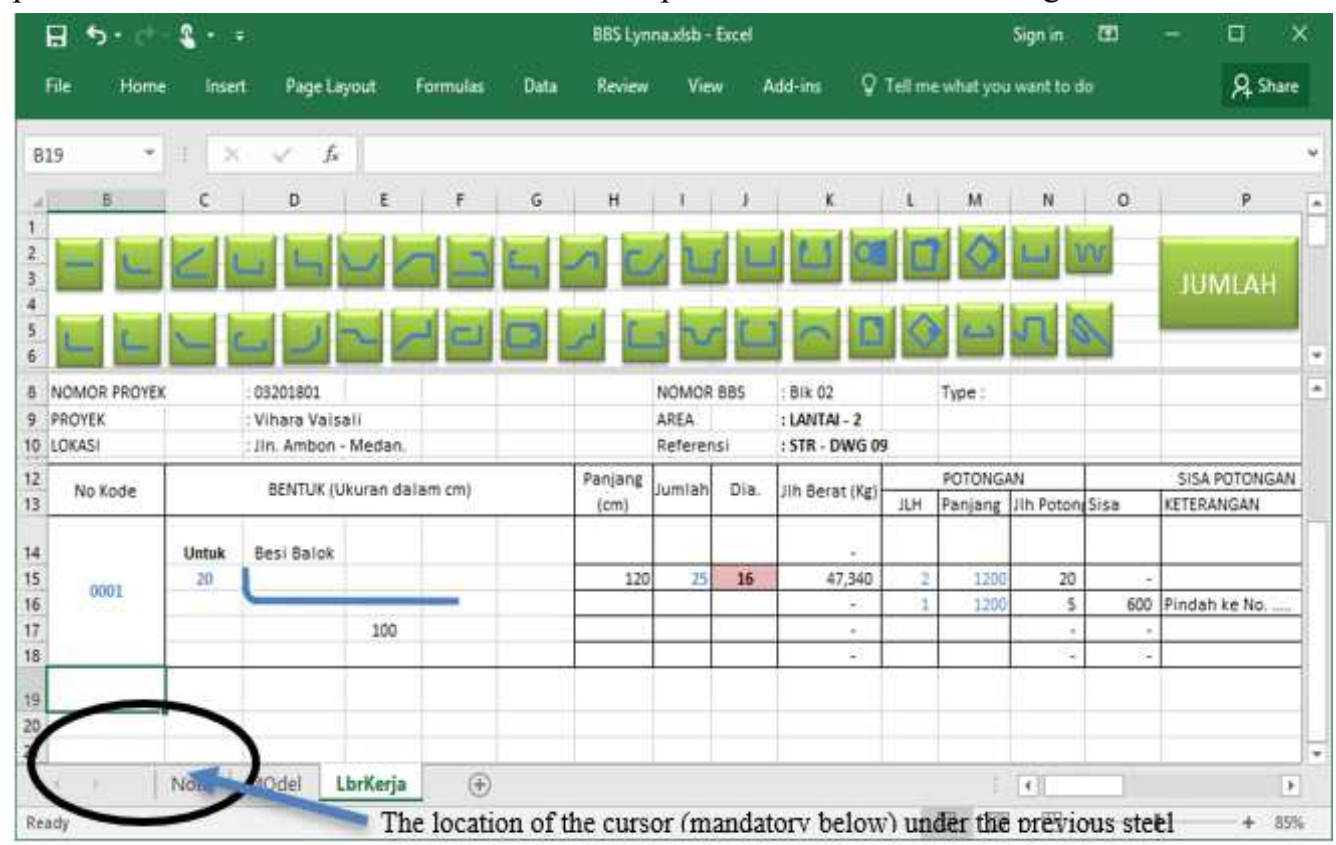

Figure 8 Advanced data input 
The next stage is the same process as the stage in Figure 4 according to the work drawings. Then after all models are inputted based on work drawings, the next step is to pay attention to the calculation of the length of remaining steel which can be used in the other reinforcement models shown in Figure 9.

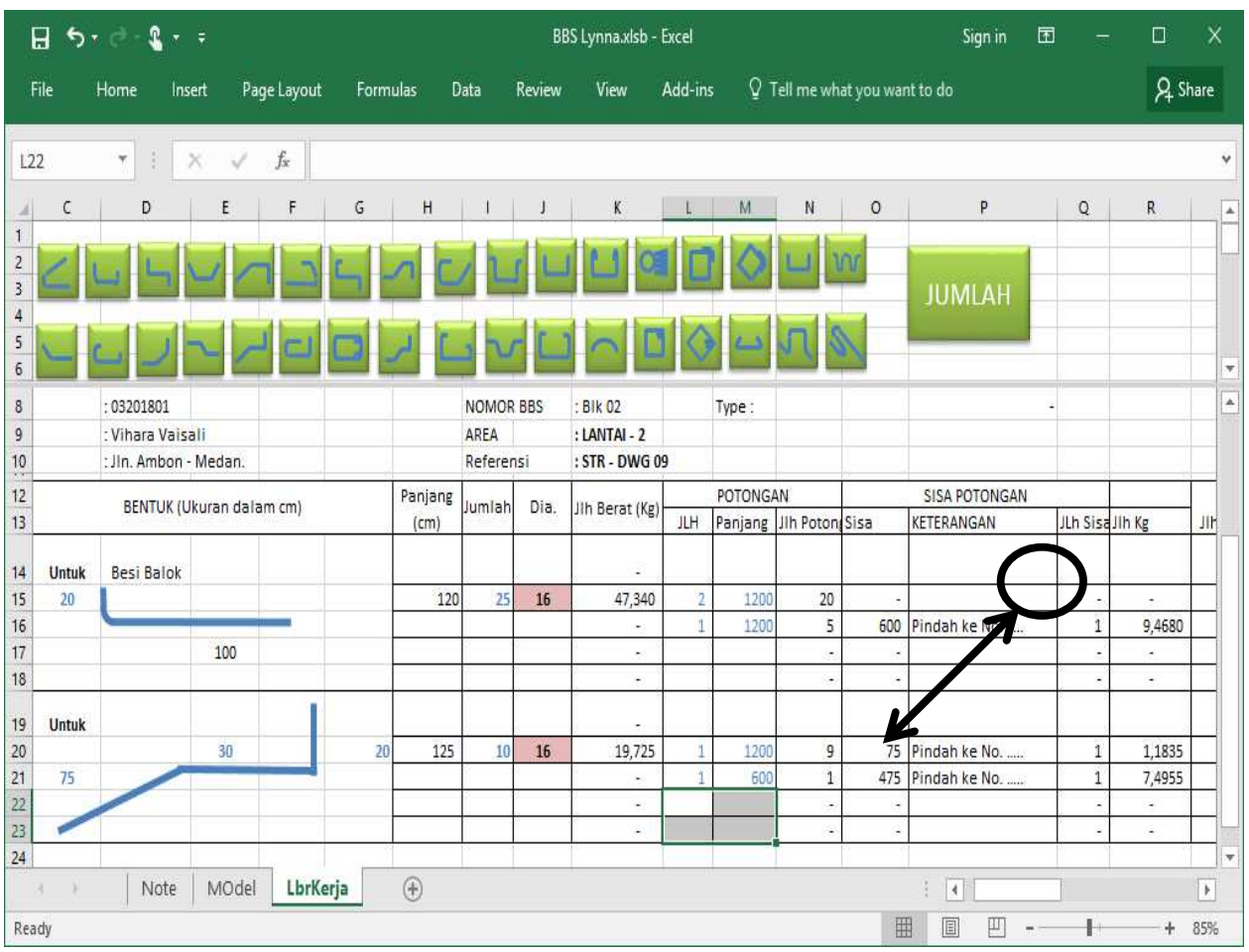

Figure 9 The process of transferring residual steel

After all the pictures and calculations are inputted, the next step is to see the number of steel usage, steel diameter and the model that will be displayed in Figure 10. Place the cursor on the 145th row position and click the number then you will see the total steel usage in accordance with the diameter desired. 


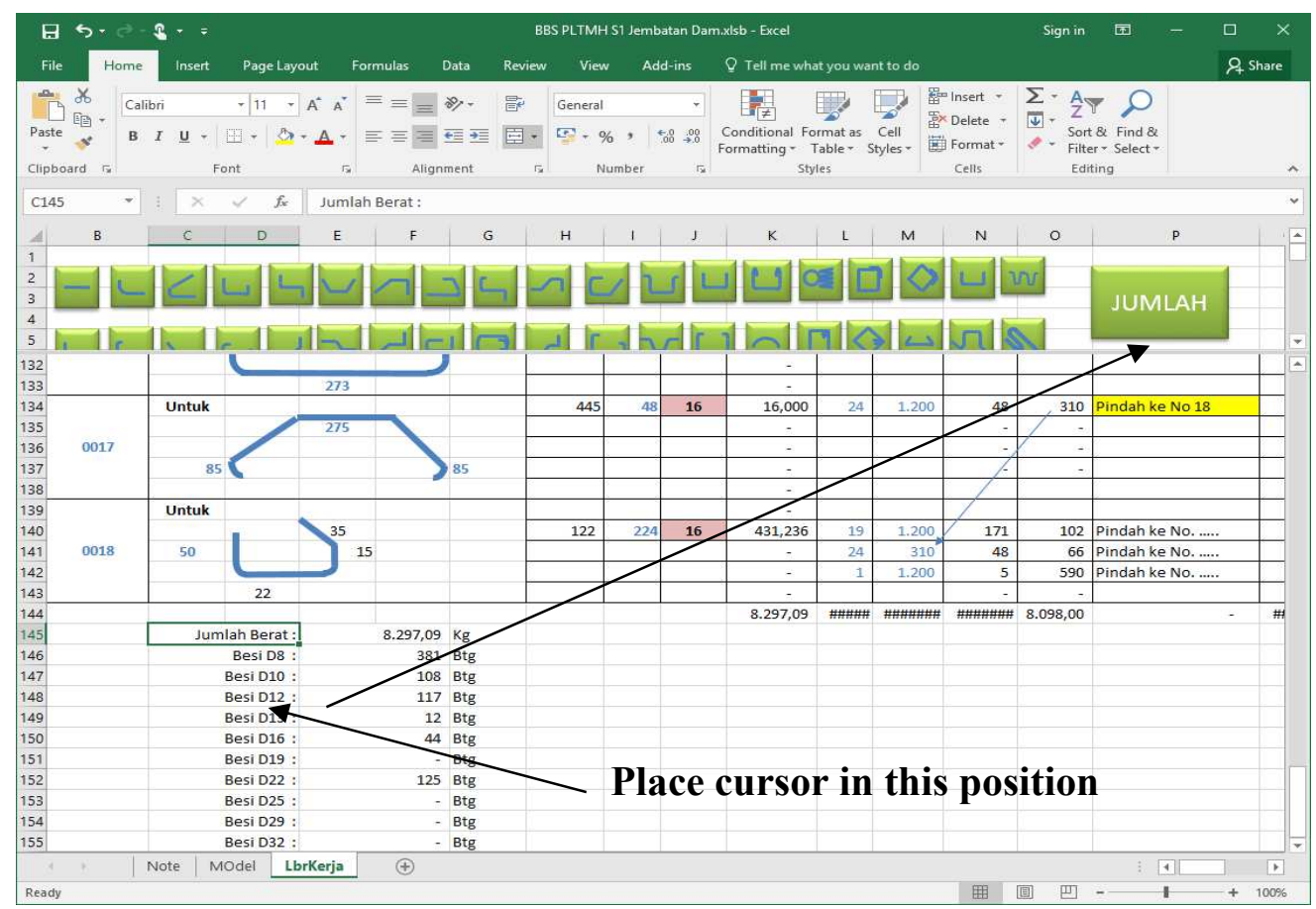

Figure 10 the amount of steel used

In Figure 10 shows the results needed for the model, diameter and amount of steel as a guide for the contractors to cut steel size and the amount in accordance with the calculations size that has been done and Excel Macros.

\section{Conclusion}

Based on the results and discussion it can be concluded that, with the use of Excel macro features, it can improve the work estimation of plan consultants and contractor to be more effective and efficient. The effectiveness of work estimation is obtained in calculations in determining the amount, model of reinforcement, dimension, code and amount of residual material. The findings are very useful for the plan consultants and contractor.

\section{References}

[1] Soeparto, G. and Trigunarsyah, B. Industri Konstruksi Indonesia: Masa Depan dan Tantangannya, Peringatan 25 tahun Pendidikan MRK diIndonesia, Civil Engineering departemen, Bandung Institute of Technology, (2013).

[2] Pramudyo, Anung. Mempersiapkan Sumber Daya Manusia Indonesia Dalam Menghadapi Masyarakat Ekonomi ASEAN Tahun 2015, Yogyakarta : YPK Yogyakarta, (2014). 
[3] Walkenbach,, J . Microsoft Excel 2010 formulas, Published by Willey Publishing Indiana polish, (2010).

[4] Sung, CTB. Building mathematical models in Excel: A guide for agriculturists, Universal Publisher.com (2015).

[5] Abisatya, PW., Pengembangan Model Root Cause Analysis Untuk Proses Pengambilan Keputusan Terkait Perbaikan Kualitas, UGM Student Thesis (2013).

[6] Creswell:John W. Research Design Pendekatan Metode kualitatif,kuantitatif dan campuran ed.4. :Pustaka Pelaja, 217 AD.Pustaka Pelajar.Jogyakarta, (2014).

[7] A.s. Ahmar, et. al., “ Modeling Data Containing outliers using ARIMA Additive Outlier (ARIMA-AO)," J.Phys. Conf.Ser., Vol 954, no.1, (2018)

[8] Poerwandari, Kristi, E. Pendekatan Kualitatif untuk Penelitian Perilaku Manusia. Depok: LPSP3, (2009).

[9] Sugiono. Metode Penelitian Kuantitatif, Kualitatif dan R\&D. Bandung: Alfabeta, (2008).

[10] Lestari, et al. Pembuatan program perataan parmeter jaring poligon dengan menggunakan visual basic for feature (VBA) microsoft excel, Jurnal Geodesi Undip.Nol.3 No. 1, (2014).

[11] Randjali, E and Riupassa, RD.. Simulasi Benda yang dilepas horizontal dan benda yang dijatuhkan vertikal menggunakan VBA pada Microsoft Excel, Prosiding SKF, ISBN: 978-60261045-1-9, (2016).

[12] Putri, TLK, et al. Perancangan sistem informasi manajemen Health \& safety Envsteelmenth dengan menggunakan microsoft excel 2007 dan makro VBA. Jurnal Rekayasa dan manajemen sistem Industri Vol.2 No.4 2014 page 750, (2014).

[13] Nugroho, PK, et al. Perancangan Perangkat Lunak Menggunakan Macro Microsoft Excel Untuk Proses Perhitungan dan Penyajian Data Audit Energi, Jurnal Transient, Vol.1, no. 4, (2012). 